\title{
IMPLEMENTASI KOMUNIKASI DALAM MENINGKATKAN MINAT PELANGGAN MENGGUNAKAN LISTRIK PRABAYAR TERHADAP KENERJA PT. PLN (PERSERO) RAYON KETAPANG
}

\author{
Mohammad Amir Furqon ${ }^{1)}$ Taufik Rahman ${ }^{2)}$ Syaiful $^{3)}$ \\ Email: Taufikrahman 1960@ gmail.com
}

\author{
Universitas Madura
}

\begin{abstract}
ABSTRAK
Penelitian ini bertujuan untuk mengetahui seberapa besar pengaruh secara simultan maupun parsial promosi (Advertising, Personal Selling, Direct Marketing) dan untuk mengetahui pengaruh yang lebih dominan terhadap minat pelanggan untuk menggunakan listrik prabayar di PT. PLN (Persero) Rayon Ketapang.

Metode pengumpulan sampel yang digunakan adalah random sampling sebanyak 99 sampel. Metode analisis ynag digunakan adalah metode regresi linier berganda (multi linier regression).

Hasil penelitian menunjukkan bahwa kualitas pelayanan (Advertising, Personal Selling, Direct Marketing) berpengaruh secara signifikan terhadap minat pelanggan untuk menggunakan listrik prabayar di PT. PLN (Persero) Rayon Ketapang. Variabel yang lebih dominan memiliki pengaruh signifikan adalah direct marketing.

Nilai koefisien diterminan ( $\mathrm{R}$ square) diperoleh 0,512 , hal ini berarti bahwa minat pelanggan dapat dijelaskan oleh ketiga variabel Advertising, Personal Selling, Direct Marketing) sebesar 51,2\% sedangkan sisanya sebesar 48,8\% dipengaruhi oleh faktor lain yang tidak dimasukkan dalam penelitian ini.
\end{abstract}

\section{Keyword : Promosi, Minat Pelanggan, dan Kinerja}

\section{PENDAHULUAN}

\subsection{Latar Belakang Masalah}

Perkembangan teknologi informasi sangat berpengaruh terhadap peningkatan kebutuhan dan keinginan masyarakat modern akan suatu layanan yang mampu memberikan kemudahan, kecepatan dan kepraktisan dalam bertransaksi. Menyikapi tuntutan tersebut maka PT. PLN (Persero) mengembangkan suatu produk layanan berbasis teknologi informasi yang disebut "Prabayar" atau "Listrik Prabayar". Sistem prabayar merupakan konsep sistem layanan baru bagi PT PLN (Persero). Sistem prabayar menjadi pilihan PT PLN (Persero) karena banyak manfaat yang bisa didapat oleh pelanggan maupun oleh PT PLN (Persero).

Walaupun PLN sudah melakukan kegiatan sosialisi terkait listrik prabayar (LBP) pada masyarakat, tetapi masih banyak ditemui kendala-kendala. Upaya untuk mengkomunikasikan produk LPB sudah dilakukan oleh PT. PLN (Persero) Rayon Ketapang, seperti melakukan program yang langsung 
berhubungan dengan masyarakat, seperti program Sarling (Pemasaran Keliling) di situ kita juga memberikan selebaran-selebaran kumunikasi tentang produk LPB, dan juga mengikuti program pameran yang diselengarakan oleh PEMDA Sampang. Namun demikian masyarakat masih banyak yang kurang memahami secara luas tentang produk terbaru yang dikeluarkan oleh PT. PLN (Persero) Rayon Ketapang. Sehingga sampai saat ini para pelanggan yang enggan untuk migrasi ke layanan listrik prabayar masih besar jumlahnya daripada pelanggan yang memakai jasa pelayanan listik prabayar.

Dalam hal ini kumunikasi juga berperan penting dalam menarik minat pelanggan untuk menggunakan listrik prabayar, karena dengan kumunikasi para pelanggan dapat mengetahui lebih banyak tentang produk yang ditawakan, sehingga ketika para pelanggan (pelanggan baru atau lama) sudah tertarik dengan kumunikasi yang ditawarkan maka akan besar kemungkinan mereka akan mengetahui nilai plus dari listrik prabayar dan akhirnya mereka kan memakai atau beralih untuk menggunakan listrik prabayar.

Berdasarkan latar belakang penelitian itulah, maka penulis tertarik untuk mengadakan penelitian yang berjudul "Implementasi Komunikasi Dalam Meningkatkan Minat Pelanggan Untuk Menggunakan Listrik Prabayar terhadap Kinerja PT.PLN (Persero) Rayon Ketapang"

\subsection{Rumusan Masalah}

Dari latar belakang masalah yang telah diuraikan di atas, pokok masalah yang dikaji dalam penelitian ini, dapat dirumuskan sebagai berikut

1. Apakah kumunikasi yang terdiri dari : Advertising ( $X_{1}$ ), Personal Selling $\left(X_{2}\right), \quad$ dan Direct Marketing $\left(\mathrm{X}_{3}\right)$ berpengaruh secara simultan terhadap minat pelanggan untuk menggunakan Listrik prabayar di PT PLN (Persero) Rayon Ketapang?

2. Variabel manakah yang lebih dominan berpengaruh terhadap minat pelanggan untuk menggunakan listrik prabayar di PT PLN (Persero) Rayon Ketapang.

\section{TINJAUAN PUSTAKA DAN HIPOTESIS}

\subsection{Kajian Teoritik}

\subsubsection{Kajian Teoritik Pemasaran}

Pemasaran adalah suatu proses sosial yang di dalamnya individu dan kelompok, mendapatkan apa yang mereka butuhkan dan inginkan dengan menciptakan, menawarkan dan secara bebas mempertukarkan produk yang bernilai dengan pihak lain (Kotler,2008:87). Menurut Jefkins (2004:107), pemasaran (marketing) sebenarnya lebih dari sekedar mendistribusikan barang dari produsen pembuatnya ke para konsumen pemakainya. Pemasaran meliputi semua tahapan, yaitu mulai penciptaan produk hingga mulai ke pelayanan purna jual setelah transaksi penjualan itu sendiri.

\subsubsection{Komunikasi Pemasaran}

Pemasaran modern tidak hanya membutuhkan pengembangan produkyang baik, pemberian harga yang menarik, dan membuatnya tersedia bagi pelanggan sasaran 
tetapi juga harus berkomunikasi harus melakukan komunikasi dengan pelanggannya baik pelanggan lama maupun calon pelanggan potensial (Kotler, 2008:141).

Dalam mempersiapkan komunikasi pemasaran, tugas pertama komunikator adalah mengenali audiens sasaran dan karakteritiknya.

Berikutnya,komunikator harus menentukan respon yang dicari, apakah itu kesadaran, pengetahuan, rasa suka, preferensi, atau pembelian.Kemudian harus dibuat suatu pesan yang isi dan strukturnya efektif.Media harus diseleksi baik untuk komunikasi pribadi maupun nonpribadi. Akhirnya, komunikator harus

mengumpulkan umpan balik dengan mengamati seberapa besar pasar yang menjadi sadar, mencoba produk, dan puas terhadap prosesnya.

\subsubsection{Tinjauan Teoritik Promosi}

Penggunaan berbagai alat dalam melakukan promosi ini merupakan cara terbaik untuk dapat menyampaikan pesan tentang produk kepada target konsumennya secara efektif.

Salah satu usaha dalam
bidang pemasaran
meningkatkan penjualanya itu melalui kegiatan promosi. "Promosi adalah berbagai cara untuk menginformasikan, membujuk, dan mengingatkan konsumen secara langsung tentang suatu produk atau brand yang dijual" ( Kotler, 2009 : 510).

Menurut Kotler danAmstrong ( 2008: 116) " bauran promosi merupakan paduan spesifik iklan, promosi penjualan, hubungan masyarakat, penjualan personal, dan sarana pemasaran langsung yang digunakan perusahaan untuk mengkomunikasikan nilai pelanggan secara persuasive dan membangun hubungan pelanggan.

Promotional mix adalah kombinasi strategi yang paling baik dari variabel-varibel periklanan, personal selling dan alat-alat promosi lainnya, yang kesemuanya dirancang untuk mencapai tujuan program penjualan. Untuk melaksanaan tujuan dan sasaran promosi yang telah ditetapkan, perusahaan dapat memilih dan menetapkan elemenelemen promosi yang dapat digunakan sebagai alat untuk mencapai sasara-sasaran yang dituju. Meskipun secara umum elemenelemen promosi yang dapat digunakan sebagai alat untuk mencapai fungsi yang sama, tetapi elemen-elemen tersebut dapat dibedakan berdasarkan tugas-tugas khusus yang akan dilakukan ( Angipora,2007:112).

Menurut shimp (2003:111) mengemukakan bahwa promosi mengacu pada setiap insentif yang digunakan oleh produsen untuk memicu transaksi ( pedangan besar dan ritel) atau untuk membeli suatu merek serta mendorong tenaga penjualan untuk secara agresif menjualnya. Dengan kegiatan promosi yang dilakukan, perusahaan akan berusaha untuk membujuk calon pembeli dan langganan untuk melakikan pembelian atas produk yang dipasarkan, dalam hal ini perusahaan melakukan komunikasi dengan konsumen.

Dapat ditarik kesimpulan bahwa inti dari kegiatan promosi 
adalah suatu bentuk kegiatan komunikasi pemasaran yang berusaha untuk menyebarkan informasi, memengaruhi, mengingatkan pasar sasaran agar bersedia menerima, membeli, dan loyal pada produk yang ditawarkan oleh perusahaan yang bersangkutan.

Mengutip dari pendapat Kotler (2005: 264-312), "unsur bauran promosi (promotion mix) terdiri atas lima perangkat utama, yaitu: Advertising, sales promotion, public relation (hubungan masyarakat), personal selling, dan direct marketing”.

\subsubsection{Macam-macam promosi a. Iklan (Advertising)}

"Iklan merupakan suatu bentuk komunikasi massa, misalnya radio, surat kabar, majalah dan sebagainya " ( Angipora, 2007:114). “ Iklan (Advertising) merupakan suatu bentuk penyajian dan promosi dari gagasan, barang atau jasa yang dibiayai oleh suatu sponsor tertentu yang bersifat non personal “ (Assauri, 2007:110).Kotler $(2005: 254)$ " mendifinisikan periklanan adalah semua bentuk penyajian nonpersonal, promosi ideide, promosi barang atau jasa yang dilakukan oleh sponsor yang dibayar “. Djaslim saladin (2007:129), “ mendifinisikan yang mengartikan periklanan adalah adalah semua bentuk penyajian yang sifatnya nonpersonal, dan promosi ide-ide, promosi barang-barang atau jasa yang dibayar oleh sponsor ".

Berdasarkan pendapat para ahli tentang difinisi iklan di atas maka dapat disimpulkan bahwa iklan merupakan suatu bentuk komunikasi nonpersonal mengenai suatu barang atau jasa maupun suatu ide sponsor tertentu yang dikeluarkan hanya untuk kegiatan tersebut.

\section{b. Penjualan (Personal Selling)}

"Penjaualan perorangan

(Personal Selling) merupakan penyajian secara lisan oleh perusahaan kepada satu atau beberapa calon pembeli dengan tujuan agar yang ditawarkan dapat terjual “, ( Assauri,2007:116).

Sedangkan Isnain mengemukakan (2005:93), “ penjualan perorangan merupakan kegiatan perusahaan untuk melakukan kontak langsung dengan para calo konsumen dan diharapkan akan terjadi suatu hubungan atau interaksi positif antara pengusaha dengan konsumennya “.

Chandra

(2006:119)

mengemukakan bahwa "dalam personal selling terdapat kontak secara langsung antara penjual dan pembeli, sehingga dapat menciptakan suatu komunikasi dua jalur antara pembeli dan penjual. Di samping menjelaskan atau memberitahukan tentang produk dan memebujuk pembeli sebagai umpan balik bagi perusahaan (Isnain,2005:94)".

Jadi dapat ditarik kesimpulan bahwa personal selling adalah suatu kegitan mempromosikan produk dengan cara presentasi secara lisan dengan satu atau lebih calon pembeli dengan tujuan melakukan penjualan. Dalam presentasi terjadi interaksi langsung natar seller dan calon pembeli.

Dalam banyak hal, personal selling sering merupakan alat yang cukup efektif dalam membangun 
preferensi, keyakinan dan tindakan pembelian, tetapi sulit melakukan pengurangan biaya, karena berkaitan dengan jumlah seller yang sulit diubah.

\begin{tabular}{|c|c|}
\hline Rambat & \\
\hline 2013:107), & $\begin{array}{l}\text { Personal } \\
\text { manfaat }\end{array}$ \\
\hline
\end{tabular}

a. Personal confrontation

Mencakup hubungan yang dinamis, harmonis, langsung dan interaktif antar dua pelanggan atau calon pelanggan atau lebih.Pengamatan personal membentuk kemampuan untuk saling menyesuaikan.

a. Cultivation

Memungkinkan timbulnya berbagai jenis hubungan mulai dari hubungan penjualan sampai ke hubungan persahabatan. Penjualan personal akan sangat efektif apabila seller mengutamakan kepentinagan pelanggan guna mempertahankan hubungan pembelian jagka panjang.

b. Respons

Membuat calon pembeli merasa berkewajiban untuk mendengarka pembicaraan seller.karena pembeli terkadang terpaksa harus menanggapi walaupun hanya sekadar ucapan "terimakasih" secara sopan.

Sifat penjualan perseorangan dapat dikatakan lebih luwes karena tenaga penjulan dapat secara langsung menyesuaikan penawaran penjualan dengan kebutuhan dan peilaku masing-masing calon pembeli. Selain itu, tenaga penjualan juga dapat dapat segera mengetahui reaksi calon pembeli terhadap penawaran penjualan sehingga dapat mengadakan penyesuain-penyesuain di tempat saat itu juga.

\section{c. Pemasaran Langsung (Direct Marketing)}

Menurut Chandra (2006:124), direct marketing merupakan sistem pemasaran interaktif yang menggunakan berbagai media komunikasi untuk meningkatkan respon langsung yang sifatnya spesifik dan terukur. Metode-metode pemasaran langsung dapat melalui katalog, pos, telepon, TV, TV kabel, TV interaktif, mesin fax, internet, dan lain-lain.

Empat karakteristik pemasaran langsung sebagai berikut:

1). Nonpublik (nonpublic)

Pesan biasanya ditujukan kepada orang tertentu, misalnya pengiriman surat via pos atau email, berarti yang mengetahui pesan tersebut hanya pihak terkait saja, publik tidak mengetahui.

2). Disesuaikan (costumized)

Pesan dapat disiapkan dan dirancang dengan sebaik-baiknya terlebih dahulu sebelum dikirimkan kepada orang yang bersangkutan agar ia tertarik.

3). Terbaru (up-to-date)

Pesan dapat disiapkan dengan sangat cepat sesuai dengan kondisi terkini.

4). Interaktif (interajtive)

Pesan dapat diubah sesuai tanggapan orang yang berkaitan sehingga menimbulkan suatu komunikasi yang interaktif.

\subsubsection{Fungsi dan Tujuan Promosi}

Ada 3 fungsi utama promosi yang dicapai dalam kegiatan promosi yaitu: 
1) Mencari dan mendapatkan perhatian (attention) dari calon pembeli.

Perhatian calon pembeli harus diperoleh karena ini merupakan titik awal proses pengambilan keputusan pembeli pada suatu jenis produk ataupun jasa dipastikn tidak akan membelinya.

2) Menumbuhkan ketertarikan atas barang dan jasa pada calon pembeli.

Perhatian yang sudah diberikan pada seseorang mungkin akan dilanjutkan dengan tahap berikutnya pada seseorang mungkin akan dilanjutkan dengan tahap berikutnya adalah timbulnya akan membelinya.

3) Mengembangkan keinginan (desire) pembeli untuk memilih jasa atau produk yang ditawarkan. Hal ini merupakan kelanjutan dari tahap sebelumnya. Setelah seseorang tertarik pada sesuatu maka timbul rasa ingin memilikinya, dan bila merasa maka rasa ingin semakin besar dan akan diikuti suatu keputusan yang positif.

\subsubsection{Minat Konsumen}

Menurut Marius P. Angipora, langkah pertama yang dilakukan oleh pemasar berkaitan dengan minat adalah mengestimasi jumlah konsuman yang mempunyai minat potensial untuk membeli barang dan jasa yang dihasilkan (2002:75). Minat merupakan sikap seseorang berupa produk atau aktivitas tanpa ada yang menyuruh. Menurut Ferdinand (2002:57), minat beli dapat diidentifikasikan melalui indikator-indikator sebagai berikut : a. Minat Transaksional yaitu kecendrungan seseorang untuk membeli produk.

b. Minat Refrensial yaitu kecendrungan seseorang untuk merefresikan produk kepada orang lain.

c. Minat Preferensial yaitu minat yang menggambarkan perilaku seseorang yang memiliki preferensi ini hanya dapat diganti jika terjadi sesuatu dengan produk preferensinya.

d. Minat Transksional

Minat Eksploratif yaitu minat yang menggambarkan perilaku seseorang yang selalu mencari informasi mengenai produk yang diminatinya dan mencari informasi untuk mendukung sifatsifat positif dari produk tersebut.

\subsection{HIPOTESIS}

Berdasarkan latar belakang masalah, rumusan masalah, dan kerangka pemikiran yang telah dikemukakan di atas, maka penulis merumuskan sebuah hipotesis penelitian sebagai berikut :

1. Promosi yang terdiri dari advertising, personal selling, dan direct marketing berpengaruh secara simultan terhadap minat pelanggan untuk menggunakan listrik prabayar di PT. PLN (Persero) Rayon Ketapang.

2. Variabel yang dominan berpengaruh terhadap minat pelanggan menggunakan listrik prbayar di PT. PLN (Persero) Rayon Ketapang adalah variabel direct marketing. 


\section{METODE PENELITIAN}

\subsection{Lokasi Penelitian}

Penelitian ini dilakukan di PT. PLN (Persero) Rayon Ketapang, lokasi tersebut dianggap layak untuk diteliti karena Rayon ini memiliki karakteritik yang berbeda dibandingkan Rayon-Rayon yang ada di Madura terkait budaya dan pola masyarakatnya sebagai konsumen akhir khususnya dalam hal pemenuhan kewajiban dari pelanggan terhadap pembayaran rekening listrik yang telah dibebankan oleh PLN.

\subsection{Jenis dan Sumber Data}

\subsubsection{Jenis Data}

Jenis data yang dikumpulkan dalam penelitian ini berupa data bersifat kuantitatif (merupakan data yang berbentuk data angka) dan data kualitatif yaitu (data yang sifatnya menggolongkan saja).

\subsubsection{Sumber Data}

Sumber data dalam penelitian ini ada dua jenis (Sugiono,2015:193) yaitu:

1. Data Primer

Dalam penelitian ini, yang berasal dari kuesioner dan wawancara langsung kepada pelanggan listrik prabayar di PT. PLN (Persero) Rayon Ketapang.

2. Data Sekunder

Data sekunder ini digunakan oleh peneliti untuk memberikan gambaran tambahan, gambaran pelengkap atau untuk diproses lebih lanjut.

\subsection{Populasi dan Pampel}

\subsubsection{Populasi}

Populasi dalam penelitian ini yaitu semua pelanggan PT. PLN (Persero) Rayon Ketapang sebanyak
7.865 Pelanggan (Pelanggan Listrik Prabayar).

\subsubsection{Sampel}

Untuk penentuan sampel menggunakan rumus Slovin. Berdasarkan perhitungan, jumlah sampel yang diteliti berjumlah 99 orang pelanggan. Teknik pengambilan sampel yang digunakan pada penelitian ini adalah random sampling.

\subsection{Definisi Operasional Variabel.}

Definisi opersional dalam variabel penelitian ini adalah:

1. Variabel bebas (X) yaitu Promosi

2. Advertising $\left(\mathrm{X}_{1}\right)$ adalah merupakan suatu bentuk penyajian dan promosi dari gagasan, barang atau jasa yang dibiayai oleh suatu sponsor tertentu yang bersifat non personal, dapat diukur dengan indikator sebagai berikut:
a. Message
b. Media
c. Daya tarik pesan

3. Personal Selling $\left(\mathrm{X}_{2}\right)$ adalah Penjaualan perorangan (Personal Selling) merupakan penyajian secara lisan oleh perusahaan epada satu atau beberapa calon pembeli dengan tujuan agar yang ditawarkan dapat terjual, dapat diukur dengan :
a. Presentasi
b. Menghilangkan keberatan
c. Kejelasan informasi
d. Penutupan penjualan

4. Direct Marketing $\left(\mathrm{X}_{3}\right)$ adalah merupakan sistem pemasaran interaktif yang menggunakan berbagai media komunikasi untuk meningkatkan respon langsung yang sifatnya spesifik dan terukur, dapat diukur dengan :

a. Ketepatan waktu 
b. Kesopanan sifat saat berbicara

c. kesusaian tarif yang ditawarkan dengan manfaat yang diterima

5. Variabel terikat yaitu minat konsumen (Y) adalah tahap kecendrungan konsumen untuk bertindak sebelum keputusan membeli benar-benar dilakukan.
a. Minat transaksional
b. Minat refrensial
c. Minat preferensial
d. Minat eksploratif

\subsection{Pengujian Istrumen Data}

\subsubsection{Uji Validitas}

Data dikatakan valid apabila $r$ hitung lebih besar ( > ) dari r tabel. Selain itu juga bisa dilihat dari signifikasinya, jika nilai signifikasinya lebih besar dari 0,05 maka data tersebut dapat dikatakan tidak valid. Jika nilai signifikannya lebih kecil dari 0,05 maka data tersebut dikatakan valid (Yarnest, 2003:65). Selain itu data dikatakan valid apabila memiliki koefisien korelasi > 0,3 (Sudarmanto, 2005:88). Dengan demikian semua pertanyaan atau pernyataan tersebut dapat digunakan dan dapat dipercaya untuk mengumpulkan data yang diperlukan.

\subsubsection{Uji Reliabilitas}

Pengujian keandalan alat ukur dalam penelitian ini menggunakan reliabilitas metode cronbach alpha (Danim,2000:199),

Kriteria suatu instrumen dikatakan reliabel dengan menggunakan teknik ini, bila koefisien reliabilitasnya $\left(\mathrm{r}_{11}\right)>0,60$ (Sugiono, 2015 :132).

\subsection{Teknik Analisis Data dan Uji Hipotesis}

\subsubsection{Teknik Analisis Data}

Pada penelitian ini terdiri dari dua analisis yang yang terdiri dari analisis kualitatif dan analisis kuantitatif.

a. Analisis kualitatif

Analisis diskriptif kualitatif adalah untuk memberikan gambaran tentang obyek yang akan diteliti, dengan menggunakan skala linkert.

b. Analisis kuantitatif

Analisis kuantitatif adalah suatu analisa dengan menggunakan perhitungan berdasarkan angkaangka dari olahan data yang didapat dengan tujuan untuk memberikan gambaran tentang kondisi obyek yang diteliti berdasarkan perhitungan statistik. Adapun teknik ini dengan menggunakan:

1. Uji Asumsi Klasik

Uji asumsi klasik dilakukan untuk mengetahui suatu model regresi yangdigunakan dalam penelitian ini termasuk layak atau tidak layak. Uji asumsi klasik juga untuk menilai baik tidaknya model regresi yang dikembangkan (Singgih Santoso,2009:342).Adapun ujiasumsi klasik meliputi:

a. Uji Multikolineritas

Uji multikolineritas bertujuan untuk menguji ada tidaknya korelasi antara variabel independent (bebas). Uji multikolineritas dalam penelitian ini dilakukan dengan melihat nilai variance inflation factor (VIF).

b. Uji Linieritas

“ Uji linieritas digunakan untuk melihat apakah spesifikasi model yang digunakan sudah benar atau tidak" (Imam Ghozali). Hal tersebut didukung oleh pendapat Purbaya Budi Santoso dan Ashari tentang asumsi linieritas : asumsi ini menyatakan bahwa untuk persamaan regresi linier, hubungan antara 
variabel independen $\mathrm{dn}$ dependen harus linier".

2. persamaan regresi linier berganda. $\mathbf{Y}=\mathbf{a}+\mathbf{b}_{1} \mathbf{X}_{1}+\mathbf{b}_{2} \mathbf{X}_{2}+\mathbf{b}_{3} \mathbf{X}_{3}+e$ Dimana : $Y=$ variabel terikat yang ditentukan oleh besarnya $\mathrm{X}$ $\mathrm{X}=$ Variabel bebas yang menentukan besarnya $\mathrm{Y}$ $\mathrm{b}=$ Koefisien korelasi

$$
\begin{aligned}
& \mathrm{a}=\text { Nilai konstanta } \\
& \mathrm{e}=\text { error }
\end{aligned}
$$

Untuk mengetahui besarnya pengaruh yang diberikan oleh variabel bebas terhadap variabel terikat dalam hal ini sering disebut dengan koefisien determinan atau $\mathrm{R}$ squared. Menyebutkan bahwa perhitungan koefisien determinasi berganda digunakan untuk mengukur ketepatan dari model analisis yang dibuat. Nilai koefisien determinasi berganda digunakan untuk mengukur besarnya sumbangan dari variabel bebas yang diteliti terhadap variabel terikat. Nilai $\mathrm{R}^{2}$ berada antara 0 dan 1 atau $0 \leq \mathrm{R}^{2} \leq 1$. Bila nilai $\mathrm{R}^{2}$ mendekati nilai 1 maka dapat dikatakan semakin besar, berarti model yang digunakan semakin kuat untuk menerangkan variasi dari variabel terikat. Sedangkan jika $\mathrm{R}^{2}$ nilai mendekati 0 maka model yang digunakan semakin lemah dalam menerangkan variasi dari variabel terikat.

\subsubsection{Uji Hipotesis}

Analisis data dilakukan dengan mengukur tingkat kolerasi antara variabel terikat dengan variabel bebas, sedangkan pengelolaan datanya menggunakan bantuan komputer dengan program
SPSS. Hal ini didasarkan oleh dua pertimbangan yaitu :

1. Mempercepat proses analisis.

2. Diharapkan dapat memberikan hasil yang lebih akurat dan tepat.

\subsubsection{Pengujian regresi secara simultan ( Uji F)}

Untuk menguji hipotesis komparatif lebih dari dua rata-rata sampel ( $\mathrm{k}$ sampel ) digunakan teknis statistik yang disebut analisis varians.

- apabila hasil perhitungan menunjukkan :

1. $\mathrm{Fh}>\mathrm{Ft}$ atau probalilitas kesalahan kurang 5\%, maka Ho ditolak dan Ha diterima. Ini berarti bahwa variabel dari model regresi berhasil menerangkan variabel bebas secara keseluruhan.

2. $\mathrm{Fh}<\mathrm{Ft}$ atau probabilitas kesalahan lebih dari 5\%, maka Ho diteriman dan Ha ditolak. Ini berarti bahwa variasi dari model regresi tidak berhasil menerangkan variasi dari model regresi tidak berhasil menerangkan variasi variabel bebas secara keseluruhan.

\subsubsection{Pengujian regresi secara parsial ( Uji t ) \\ Untuk regresi berganda} apakah signifikan atau tidak menggunakan $t_{\text {hitung yaitu untuk }}$ mengetahui sumbangan masingmasing variabel bebas secara parsial terhadap variabel terikat,

Dengan membandingkan $t_{\text {hitung }}$

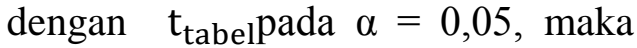
pengambilan keputusannya adalah sebagai berikut :

Bila $t_{\text {hitung }} \leq t_{\text {tabel }}$, maka hipotesis nol (Ho) diterima, hipotesis alternatif (Ha) ditolak, berarti variabel-variabel 
bebas kurang dapat menjelaskan variabel terikatnya. Sebaliknya bila $t_{\text {hitung }} \geq t_{\text {tabel }}$, maka Ho ditolak Haditerima. Dengan demikian dapat dikatakan bahwa variabel-variabel bebas mampu menjelaskan variabel terikatnya.

\section{HASIL PENELITIAN DAN PEMBAHASAN}

\subsection{Hasil Penelitian}

\subsubsection{Gambaran Umum Objek Penelitian}

\section{Sejarah Singkat dan Profil PT PLN (Persero).}

Kelistrikan di Indonesia dimulai sekitar Tahun 1898, Pemerintahan Hindia Belanda mendirikan perusahaan listrik untuk pertama kalinya di Indonesia. Pada saat itu pengelolaannya dilakukan dan dikembangkan secara patungan antara Pemerintah Hindia Belanda dengan perusahaan listrik milik swasta.

Pembangunan kelistrikan yang dikelola daerah setempat seperti Electriciteit Bedrijf Batavia (1893), Electriciteit Bedrijf Medan (1903), Electriciteit Bedrijf Surabaya (1907), dialihkan ke perusahaan swasta. Setelah masa itu, perusahaan listrik yang berpusat di negeri
Belanda juga didirikan di wilayah Indonesia.

Status perusahaan Umum Listrik Negara berubah menjadi PT PLN (Pesero) sesuai PP RI No. 23/1994 terhitung mulai tanggal 1 Agustus 1994, dengan perubahan visi perusahaan, yaitu : efisiensi, tumbuh dan berkembang, citra baik. Kemudian status ini disahkan oleh Menteri Kehakiman No. C211.519.HT.01.01 Tahun 1994, serta diumumkan dalam Tambahan Berita Negara No. 6731/1994.

\subsubsection{Uji Validitas Dan Reliabilitas}

\section{a. Uji Validitas}

Untuk mengetahui kevalidan sebuah instrumen, dalam penelitian ini dilakukan pengujian dengan menggunakan teknik korelasi product moment / korelasi pearson dengan menggunakan program SPSS 21.0. Derajad kepercayaan yang digunakan dalam penelitian ini adalah sebesar 90\%. Variabel dinyatakan valid apabila koevisien korelasi $r>0,3$. Dari hasil analisis Uji Validitas Sebanyak 14 Item terbukti dari 14 Item tersebut dinyatakan Valid, yang dapat diketahui hasilnya sebagai berikut tabel 4.1:

Tabel 4.1

Hasil Uji Validitas 14 Item Yang Valid

\begin{tabular}{l|l|r|r}
\hline \multicolumn{1}{c|}{ Variabel } & \multicolumn{1}{|c|}{ Indikator } & \multicolumn{1}{c|}{$\begin{array}{c}\text { Koefisien } \\
\text { korelasi }\end{array}$} & Keterangan \\
\hline $\begin{array}{l}\text { Variabel } \\
\left(\mathbf{X}_{\mathbf{1}}\right)\end{array}$ & & & \\
\hline Item 1 & Jangkauan & 0,469 & Valid \\
\hline Item 2 & Frekuensi & 0,826 & Valid \\
\hline Item 3 & Daya tarik pesan & 0,509 & Valid \\
\hline $\begin{array}{l}\text { Variabel } \\
\left(\mathbf{X}_{\mathbf{2}}\right)\end{array}$ & & & \\
\hline Item 1 & Prospecting & 0,689 & Valid \\
\hline
\end{tabular}


ISSN 1412-2936

EISSN 2549-7308

\begin{tabular}{|c|c|c|c|}
\hline Item 2 & Comunicating & 0,457 & Valid \\
\hline Item 3 & Kejelasan Informasi & 0,605 & Valid \\
\hline Item 4 & ketepatan Informasi & 0,514 & Valid \\
\hline \multicolumn{4}{|c|}{$\begin{array}{l}\text { Variabel } \\
\left(\mathbf{X}_{3}\right)\end{array}$} \\
\hline Item 1 & Ketepatan Waktu & 0,625 & Valid \\
\hline Item 2 & Kesopanan Sifat Saat Berbicara & 0,729 & Valid \\
\hline Item 3 & $\begin{array}{l}\text { Kesesuain tarif yang ditawarkan dengan } \\
\text { manfaat yang diterima }\end{array}$ & 0,385 & Valid \\
\hline \multicolumn{4}{|c|}{ Variabel (Y) } \\
\hline Item 1 & Transaksional & 0,514 & Valid \\
\hline Item 2 & Refrensial & 0,469 & Valid \\
\hline Item 3 & Difrensial & 0,511 & Valid \\
\hline Item 4 & Eksploratif & 0,585 & Valid \\
\hline
\end{tabular}

Sumber : dari Lampiran Hasil Uji Validitas

Berdasarkan tabel 4.1, dari hasil uji validitas tersebut ternyata semua indikator valid karena koefisien korelasinya $>0,3$ sehingga semua indikator variabel dapat diikutkan dalam proses selanjutnya.

\section{b. Hasil Uji Reliabilitas}

Kehandalan alat ukur dalam penelitian ini diuji dengan menggunakan metode cronbach alpha. Tujuan dari uji reliabilitas adalah untuk mengetahui tingkat kehandalan dari instrumen penelitian. Dimana suatu variabel dapat dinyatakan reliabel/handal apabila koefisien alpha $>0,6$ dengan menggunakan metode Cronbach Alpha dengan menggunakan bantuan SPSS yang dapat dilihat pada tabel 4.2 berikut ini :

Tabel 4.2

Hasil Uji Reliabilitas

\begin{tabular}{l|l|l|l|l}
\hline Variabel & Keterangan & Koefisien Alpha & $\begin{array}{l}\text { RELIABILITAS } \\
\text { (Cronbach's } \\
\text { Alpha) }\end{array}$ & Keterangan \\
\hline X1 & Advertising & 0,684 & 0,60 & Handal \\
\hline X2 & Personal Selling & 0,696 & 0,60 & Handal \\
\hline X3 & Direct Marketing & 0,680 & 0,60 & Handal \\
\hline Y & Minat Konsumen & 0,644 & 0,60 & Handal \\
\hline
\end{tabular}

Sumber : Data diolah. 
ISSN 1412-2936

EISSN 2549-7308

Dari Tabel 4.2 dapat diketahui bahwa semua item dari pernyataan semua faktor yang terdiri atas faktor Advertising $\left(\mathrm{X}_{1}\right)$ ,Personal Selling $\left(\mathrm{X}_{2}\right)$, Direct Marketing $\left(\mathrm{X}_{3}\right)$,Miinat Konsumen (Y) mepunyai Koefisien Alpha lebih dari 0,60. Dengan demikian berarti bahwa item pernyataan untuk semua variabel dinyatakan Reliabel.

\subsubsection{Analisa Deskriptif}

\section{a. Distibusi Jawaban Responden}

\section{Frekuensi Jawaban Responden Variabel Advertising $\left(\mathbf{X}_{1}\right)$}

Berdasarkan pada hasil jawaban responden atau kuesioner tentang variabel advertising $\left(\mathrm{X}_{1}\right)$ dapat digambarkan pada tabel 4.3 berikut ini

Tabel 4.3

Distribusi Jawaban Responden Variabel Advertising $\left(\mathbf{X}_{1}\right)$

\begin{tabular}{|c|c|c|c|}
\hline No & Pertanyaan & $\begin{array}{l}\text { Jumlah } \\
\text { (Orang) }\end{array}$ & $\begin{array}{c}\text { Persentase } \\
(\%)\end{array}$ \\
\hline 1 & $\begin{array}{l}\text { Pesan yang terkandung dalam berbagai media dapat } \\
\text { dipercaya } \\
\text { a. Sangat tidak setuju } \\
\text { b. Tidak setuju } \\
\text { c. Cukup setuju } \\
\text { d. Setuju } \\
\text { e. Sangat setuju }\end{array}$ & $\begin{array}{r}8 \\
36 \\
43 \\
12 \\
\end{array}$ & $\begin{array}{r}8.1 \\
36.4 \\
43.4 \\
12.1 \\
\end{array}$ \\
\hline & Jumlah & 99 & 100.0 \\
\hline 2 & $\begin{array}{l}\text { Design media yang digunakan menarik } \\
\text { a. Sangat tidak setuju } \\
\text { b. Tidak setuju } \\
\text { c. Cukup setuju } \\
\text { d. Setuju } \\
\text { e. Sangat setuju }\end{array}$ & $\begin{array}{l}27 \\
52 \\
20 \\
\end{array}$ & $\begin{array}{l}27.3 \\
52.5 \\
20.2 \\
\end{array}$ \\
\hline & Jumlah & 99 & 100.0 \\
\hline 3 & $\begin{array}{l}\text { Iklan yang dilakukan dalam berbagai media memiliki } \\
\text { daya tarik yang bagus } \\
\text { a. Sangat tidak setuju } \\
\text { b. Tidak setuju } \\
\text { c. Cukup setuju } \\
\text { d. Setuju } \\
\text { e. Sangat setuju }\end{array}$ & $\begin{array}{l}15 \\
52 \\
20\end{array}$ & $\begin{array}{l}27.3 \\
52.5 \\
20.2\end{array}$ \\
\hline & Jumlah & 99 & 100.0 \\
\hline
\end{tabular}

Sumber : Data diolah.

Berdasarkan tabel 4.3 terlihat bahwa pada indikator message, jumlah responden yang menjawab sangat setuju sebanyak 12 orang atau sebesar $12.1 \%$, yang menjawab setuju sebanyak 43 orang atau sebesar $43,4 \%$ sedangkan yang menjawab cukup setuju sebanyak 36 orang atau sebesar $36,4 \%$. Sedangkan pada indikator media, jumlah responden yang menjawab sangat setuju sebanyak 20 orang atau 
sekitar 20,2\%, yang menjawab setuju sebanyak 52 orang atau sekitar $52,2 \%$, sedangkan yang menjawab cukup setuju sebanyak 27 orang atau sekitar 27,3\%. Pada indikator daya tarik pesan, jumlah responden yang menjawab sangat setuju sebanyak 32 orang atau sekitar 32,3\%, yang menjawab setuju sebanyak 52 orang atau sekitar $52,5 \%$, sedangkan yang menjawab cukup setuju sebanyak 15 orang atau sekitar $15,2 \%$.

\section{Frekuensi Jawaban Responden Variabel Personal Selling $\left(\mathbf{X}_{2}\right)$}

Berdasarkan pada hasil jawaban responden atau kuesioner tentang variabel personal selling $\left(\mathrm{X}_{2}\right)$ dapat digambarkan pada tabel 4.4 berikut ini

Tabel 4.4

Distribusi Jawaban Responden Variabel Personal Selling $\left(\mathbf{X}_{2}\right)$

\begin{tabular}{|c|c|c|c|}
\hline No & Pertanyaan & $\begin{array}{c}\text { Jumlah } \\
\text { (Orang) }\end{array}$ & $\begin{array}{c}\text { Persentase } \\
(\%)\end{array}$ \\
\hline \multirow[t]{2}{*}{1} & $\begin{array}{l}\text { Presentasi yang dipragakan sudah jelas dan sesuai sehingga } \\
\text { menarik minat pelanggan } \\
\text { a. Sangat tidak Setuju } \\
\text { b. Tidak Setuju } \\
\text { c. Cukup setuju } \\
\text { d. Setuju } \\
\text { e. Sangat Setuju }\end{array}$ & $\begin{array}{r}8 \\
52 \\
39\end{array}$ & $\begin{array}{r}8.1 \\
52.5 \\
39.5\end{array}$ \\
\hline & Jumlah & 99 & 100.0 \\
\hline \multirow[t]{2}{*}{2} & $\begin{array}{l}\text { Promosi yang dilakukan sudah menghilangkan keberatan } \\
\text { pelanggan } \\
\text { a. Sangat tidak Setuju } \\
\text { b. Tidak Setuju } \\
\text { c. Cukup setuju } \\
\text { d. Setuju } \\
\text { e. Sangat Setuju }\end{array}$ & $\begin{array}{l}16 \\
71 \\
12\end{array}$ & $\begin{array}{l}16.2 \\
71.7 \\
12.1\end{array}$ \\
\hline & Jumlah & 99 & 100.0 \\
\hline \multirow[t]{2}{*}{3} & $\begin{array}{l}\text { Informasi yang disampaikan jelas } \\
\text { a. Sangat tidak Setuju } \\
\text { b. Tidak Setuju } \\
\text { c. Cukup setuju } \\
\text { d. Setuju } \\
\text { e. Sangat Setuju }\end{array}$ & $\begin{array}{l}12 \\
63 \\
24\end{array}$ & $\begin{array}{l}12.1 \\
63.6 \\
24.2 \\
\end{array}$ \\
\hline & Jumlah & 99 & 100.0 \\
\hline \multirow[t]{2}{*}{4} & $\begin{array}{l}\text { Tenaga promotor tidak bersikap memaksa di penutupan } \\
\text { penjualan } \\
\text { a. Sangat tidak Setuju } \\
\text { b. Tidak Setuju } \\
\text { c. Cukup setuju } \\
\text { d. Setuju } \\
\text { e. Sangat Setuju }\end{array}$ & $\begin{array}{l}16 \\
71 \\
12 \\
\end{array}$ & $\begin{array}{l}16.2 \\
71.1 \\
12.1\end{array}$ \\
\hline & Jumlah & & \\
\hline
\end{tabular}

Sumber: Data yang diolah 
Berdasarkan tabel 4.4 bahwa pada indikator presentasi, jumlah responden yang menjawab sangat setuju sebanyak 39 orang atau sebesar 39.4\%, yang menjawab setuju sebanyak 52 orang atau sebesar $52.5 \%$ sedangkan yang menjawab cukup setuju sebanyak 8 orang atau sebesar $8.1 \%$. Sedangkan pada indikator menghilangkan keberatan, jumlah responden yang menjawab sangat setuju sebanyak 51 orang atau sekitar $51.5 \%$, yang menjawab setuju sebanyak 44 orang atau sekitar $44.4 \%$, sedangkan yang menjawab cukup setuju sebanyak 4 orang atau sekitar $4.0 \%$. Pada indikator kejelasan informasi, jumlah responden yang menjawab sangat setuju sebanyak 24 orang atau sekitar
$24.2 \%$, yang menjawab setuju sebanyak 63 orang atau sekitar $63.6 \%$, sedangkan yang menjawab cukup setuju sebanyak 12 orang atau sekitar $12.1 \%$. Pada indikator penutupan penjualan, jumlah responden yang menjawab sangat setuju sebanyak 12 orang atau sekitar 12.1 yang menjawab setuju sebanyak 71 orang atau sekitar $71,1 \%$, sedangkan jumlah responden yang menjawab cukup setuju sebanyak 16 orang atau sekitar $16.1 \%$.

3. Frekuensi Jawaban Responden Variabel Direct Marketing $\left(\mathbf{X}_{3}\right)$

Berdasarkan pada hasil jawaban responden atau kuesioner tentang variabel direct marketing $\left(\mathrm{X}_{3}\right)$ dapat digambarkan pada tabel berikut

Tabel 4.5

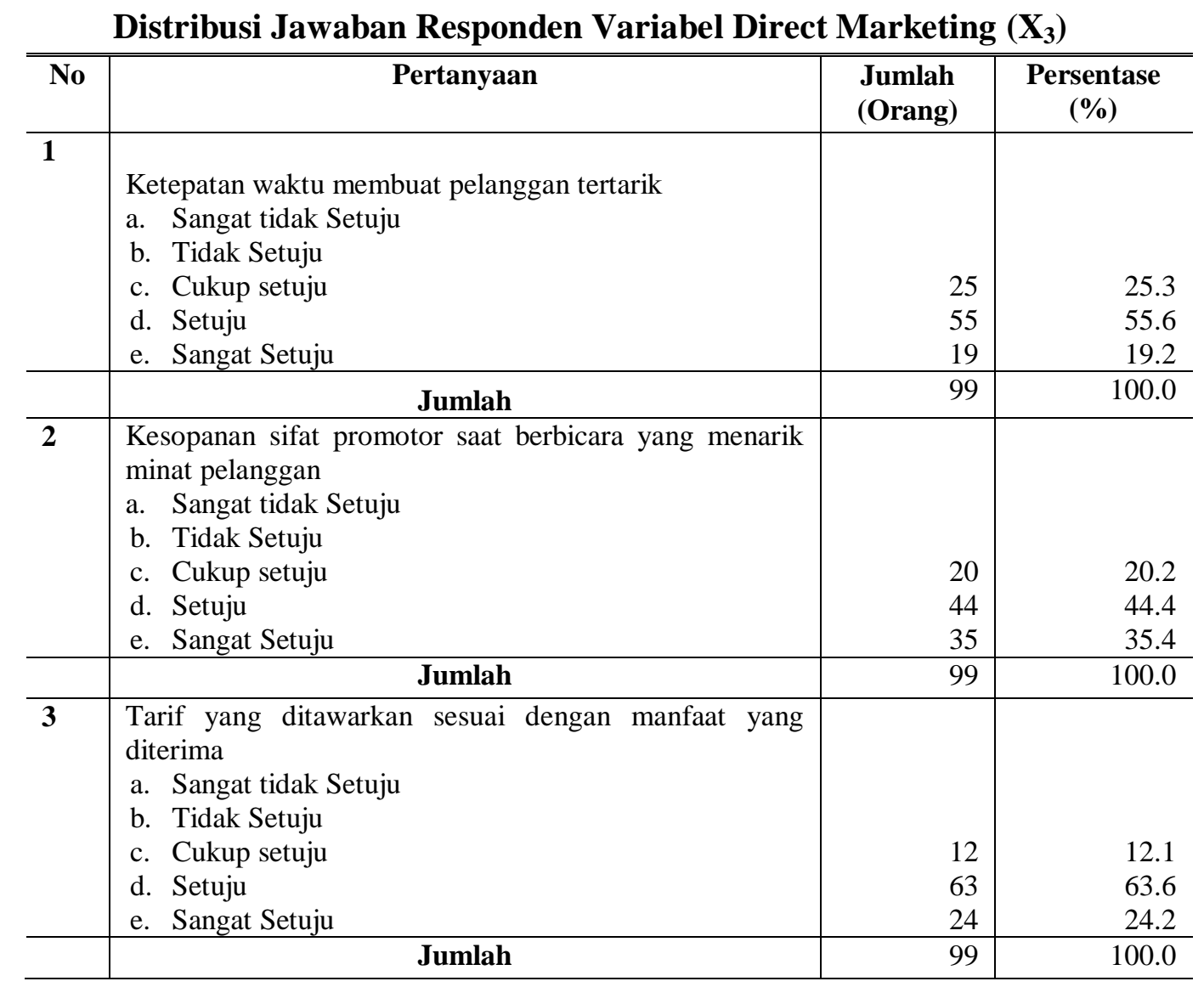


Sumber: Data yang diolah

Berdasarkan tabel 4.5 bahwa pada indikator kejelasan informasi, jumlah responden yang menjawab sangat setuju sebanyak 19 orang atau sebesar 19,2\%, yang menjawab setuju sebanyak 55 orang atau sebesar $55,6 \%$ sedangkan yang menjawab cukup setuju sebanyak 25 orang atau sebesar 25,3\%. Sedangkan pada indikator kesopanan saat berbicara, jumlah responden yang menjawab sangat setuju sebanyak 35 orang atau sekitar $35,4 \%$, yang menjawab setuju sebanyak 44 orang atau sekitar $44,4 \%$, sedangkan yang menjawab cukup setuju sebanyak 20 orang atau sekitar 20,2\%. Pada indikator kesesuaian tarif yang ditawarkan dengan yang diterima, jumlah responden yang menjawab sangat setuju sebanyak 24 orang atau sekitar $24,2 \%$, yang menjawab setuju sebanyak 63 orang atau sekitar $63,6 \%$, sedangkan yang menjawab cukup setuju sebanyak 12 orang atau sekitar $12,1 \%$.

\section{Frekuensi Jawaban Responden Variabel Kinerja Perusahaan (Y)}

Berdasarkan pada hasil jawaban responden atau kuesioner tentang variabel Kinerja Perusahaan (Y) dapat digambarkan pada tabel4.6 berikut

Tabel 4.6

Distribusi Jawaban Responden Variabel Kinerja Perusahaan(Y)

\begin{tabular}{|c|c|c|c|}
\hline No & Pertanyaan & $\begin{array}{l}\text { Jumlah } \\
\text { (Orang) }\end{array}$ & $\begin{array}{l}\text { Persentase } \\
(\%)\end{array}$ \\
\hline 1 & $\begin{array}{llll}\text { Kecendrugan pelanggan untuk munggunakan } & \text { listrik } \\
\text { prabayar } & & \\
\text { a. Sangat tidak Setuju } & & & \\
\text { b. Tidak Setuju } & & & \\
\text { c. Cukup setuju } & & & \\
\text { d. Setuju } & & \\
\text { e. Sangat Setuju } & & & \\
\end{array}$ & $\begin{array}{l}20 \\
39 \\
40 \\
\end{array}$ & $\begin{array}{l}20.2 \\
39.4 \\
40.4 \\
\end{array}$ \\
\hline & Jumlah & 99 & 100.0 \\
\hline 2 & 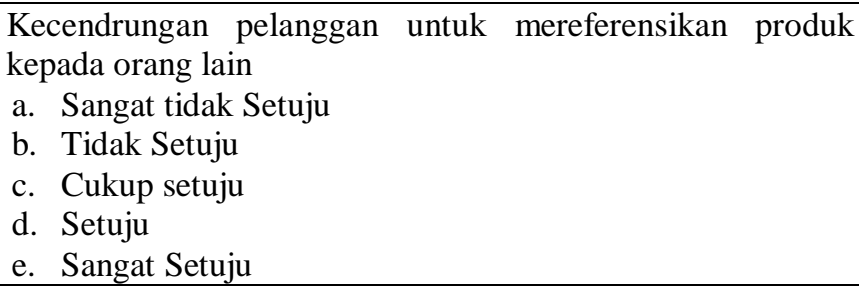 & $\begin{array}{l}48 \\
51 \\
\end{array}$ & $\begin{array}{l}48.5 \\
51.1\end{array}$ \\
\hline & Jumlah & 99 & 100.0 \\
\hline 3 & $\begin{array}{l}\text { Kesediaan pelanggan untuk membayar produk (listrik } \\
\text { prabayar) } \\
\text { a. Sangat tidak Setuju } \\
\text { b. Tidak Setuju } \\
\text { c. Cukup setuju } \\
\text { d. Setuju } \\
\text { e. Sangat Setuju }\end{array}$ & $\begin{array}{l}16 \\
71 \\
12 \\
\end{array}$ & $\begin{array}{l}16.2 \\
71.7 \\
12.1\end{array}$ \\
\hline
\end{tabular}


ISSN 1412-2936

EISSN 2549-7308

\begin{tabular}{|c|c|c|c|}
\hline No & Pertanyaan & $\begin{array}{l}\text { Jumlah } \\
\text { (Orang) }\end{array}$ & $\begin{array}{c}\text { Persentase } \\
(\%)\end{array}$ \\
\hline & Jumlah & 99 & 100.0 \\
\hline 4 & $\begin{array}{l}\text { Menceritakan hal yang positif } \\
\text { a. Sangat tidak Setuju } \\
\text { b. Tidak Setuju } \\
\text { c. Cukup setuju } \\
\text { d. Setuju } \\
\text { e. Sangat Setuju }\end{array}$ & $\begin{array}{l}15 \\
52 \\
32\end{array}$ & $\begin{array}{l}15.2 \\
52.5 \\
32.3\end{array}$ \\
\hline
\end{tabular}

Sumber: Data yang diolah

Berdasarkan tabel 4.6 bahwa pada indikator transaksional, jumlah responden yang menjawab sangat setuju sebanyak 40 orang atau sebesar 40,4\%, yang menjawab setuju sebanyak 39 orang atau sebesar 39,4\% sedangkan yang menjawab cukup setuju sebanyak 20 orang atau sebesar 20,2\%. Sedangkan pada indikator refrensial, jumlah responden yang menjawab sangat setuju sebanyak 51 orang atau sekitar 51,5\%, yang menjawab setuju sebanyak 48 orang atau sekitar $48,5 \%$, .Pada indikator preferensi,

jumlah responden yang menjawab sangat setuju sebanyak 12 orang atau sekitar 912,1\%, yang menjawab setuju sebanyak 71 orang atau sekitar $71,7 \%$, sedangkan yang menjawab cukup setuju sebanyak 16 orang atau sekitar 16,2\%.

\section{b. Statistik Diskriptif}

Untuk mengetahui sejauh mana pengaruh yang diberikan oleh variabel bebas terhadap variabel terikat perlu dilakukan analisa statistik. Berdasarkan hasil perhitungan diperoleh data sebagai berikut :

Tabel 4.7

Rata-Rata Nilai Variabel Penelitian Descriptive Statistic

\begin{tabular}{l|r|r|r}
\hline & Mean & Std. Deviaion & N \\
\hline Y (Kinerja Perusahaan) & 4.2121 & 0.32215 & 99 \\
X1 (Advertising) & 3.8981 & 0.43057 & 99 \\
X2 (Personal Selling) & 4.2172 & 0.33052 & 99 \\
X3 (Direct Marketing) & 4.0708 & 0.39389 & 99 \\
\hline
\end{tabular}

Angka pada tabel 4.7 bahwa untuk variabel Advertsing $\left(\mathrm{X}_{1}\right)$ memiliki nilai mean sebesar 3,8981 dapat dibulatkan 4,00 atinya rata-rata responden menilai jaminan yang diberikan oleh PT. PLN (Persero) Rayon Ketapang Kabupaten Sampang baik.

variabel personal selling $\left(\mathrm{X}_{2}\right)$ memiliki nilai mean sebesar 4,2172 dapat dibulatkan 4,00 atinya rata-rata responden menilai jaminan yang diberikan oleh PT. PLN (Persero) Rayon Ketapang Kabupaten Sampang baik.

variabel personal selling $\left(\mathrm{X}_{2}\right)$ memiliki nilai mean sebesar 4,0708 dapat dibulatkan 4,00 atinya rata-rata responden menilai jaminan yang diberikan oleh PT. PLN (Persero) Rayon Ketapang Kabupaten Sampang baik. 
Sedangkan variabel personal selling $\left(X_{2}\right)$ memiliki nilai mean sebesar 4,2121 dapat dibulatkan 4,00 atinya rata-rata responden menilai jaminan yang diberikan oleh PT. PLN (Persero) Rayon Ketapang Kabupaten Sampang baik.

\subsubsection{Analisis Kuantitatif a. Hasil Asumsi Klasik}

1). Uji multikolineritas

bertujuan untuk menguji adan tidaknya korelasi antara variabel independent (bebas). Uji multikolineritas dalam penelitian ini dilakukan dengan melihat nilai variance inflation factor (VIF). Dengan menggunakan SPSS dan dapat diperoleh hasil sebagai berikut

tabel 4.8

Uji Multikolenieritas

\begin{tabular}{l|l|l|l|l}
\hline \multicolumn{2}{l|}{ Correlations } & \multicolumn{2}{l}{ Collinearity Statistics } \\
\hline Zero-order & Partial & Part & Tolerance & VIF \\
\hline 0,106 & 0,310 & 0,228 & 0,874 & 1,144 \\
0,455 & 0,233 & 0,167 & 0,608 & 1,646 \\
0,677 & 0,564 & 0,477 & 0,679 & 1,472 \\
\hline
\end{tabular}

a. Dependent Variable: Y (Kinerja Perusahaan)

Sumber: Data Diolah

Sesuai dengan ketentuan uji multikolenieritas, jika nilai VIF kurang dari 10 maka tidak terdapat korelasi. Berdasarkan tabel 4.9 dapat dilihat bahwa nailai VIF yaitu 1,144 kurang dari 10. Sehingga dapat disimpulakan bahwa tidak terdapat multikolenieritas dalam data penelitian ini. Artinya bahwa antara variabel bebas (advertising $\mathrm{X}_{1}$, personal selling $\mathrm{X}_{2}$,direct marketing $\mathrm{X}_{3}$ ) tidak saling mengganggu atau mempengaruhi

2). Hasil Uji Linieritas

Uji linieritas dalah pengujian yang bertujuan untuk mengetahui apakah regresi bersifat linier atau

Tabel 4.9

Uji linieritas

Anova $^{a}$ tidak. Uji linieritas dalam penelitian ini menggunakan tabel ANOVA variabel $\mathrm{X}$ dan $\mathrm{Y}$ dari nilai signifikan. Apabila nilai signifikan tabel ANOVA $<0,05$ maka dapat disimpulakan bahwa hubungan bersifat linier. Uji linier dalam penelitian ini juga menggunakan SPPS dengan hasil pengujian sebagai berikut :

\begin{tabular}{l|l|l|l|l|l}
\multicolumn{7}{c}{ Anova $^{\mathbf{a}}$} \\
\hline Model & Sum of squares & Df & Mean Square & F & Sig. \\
\hline
\end{tabular}


ISSN 1412-2936

EISSN 2549-7308

\begin{tabular}{ll|l|l|l|l|l}
\hline 1 & $\begin{array}{l}\text { Regression } \\
\text { Residual }\end{array}$ & 5.208 & 3 & 1,736 & 33,235 &, $000^{\mathrm{b}}$ \\
& 4,962 & 95 &, 052 & & \\
& Total & 10,170 & 98 & & & \\
\hline
\end{tabular}

Sumber : Data diolah.

Berdasarkan tabel 4.9 tersebut dapat dilihat bahwa nilai signifikan tabel ANOVA sebesar 0,000. Artinya nilai signifikan kurang dari 0,05 $(0,000<0,05)$ yang berarti bahwa hubungan bersifat linier. Hali ini menunjukkan bahwa advertising, personal selling, dan direct marketing berpola linier terhadap minat pelanggan.

\section{b. Hasil Persamaan Linier Berganda}

Tabel 4.10

Hasil Regresi Linear Berganda

Coefficients $^{\mathrm{a}}$

\begin{tabular}{|c|c|c|c|c|c|c|c|c|c|c|}
\hline \multirow[b]{2}{*}{ Model } & \multicolumn{2}{|c|}{$\begin{array}{l}\text { Unstandardized } \\
\text { Coefficients }\end{array}$} & \multirow{2}{*}{\begin{tabular}{|c|}
$\begin{array}{l}\text { Standardized } \\
\text { Coefficients }\end{array}$ \\
Beta \\
\end{tabular}} & \multirow[b]{2}{*}{ t } & \multirow[t]{2}{*}{ Sig. } & \multicolumn{3}{|c|}{ Correlations } & \multicolumn{2}{|l|}{$\begin{array}{l}\text { Collinearity } \\
\text { Statistics }\end{array}$} \\
\hline & B & Std. Error & & & & $\begin{array}{l}\text { Zero- } \\
\text { order }\end{array}$ & Partial & Part & Tolerance & VIF \\
\hline (Constan) & 0,692 & 0,446 & & 1,552 & 0,124 & & & & & \\
\hline $\begin{array}{l}\text { X1 } \\
\text { (Advertising) }\end{array}$ & 0,182 & 0,057 & 0,244 & 3,181 & 0,002 & 0,106 & 0,310 & 0,228 & 0,874 & 1,144 \\
\hline $\begin{array}{l}{ }^{1} \text { X2 (Personal } \\
\text { Selling) }\end{array}$ & 0,209 & 0,090 & 0,215 & 2,335 & 0,022 & 0,455 & 0,233 & 0,167 & 0,608 & 1,646 \\
\hline $\begin{array}{l}\text { X3(Direct } \\
\text { Marketing) }\end{array}$ & 0,473 & 0,071 & 0,579 & 6,654 & 0,000 & ,677 & 0,564 & 0,477 & 0,679 & 1,472 \\
\hline
\end{tabular}

a. Dependent Variable: Y (Kinerja Perusahaan)

Sumber: Data Diolah

Pada tabel 4.10 korelasi menunjukkan suatu hubungan. Korelasi antara minat pelanggan dengan advertising, minat pelanggan dengan personal selling, dan minat pelanggan dengan direct marketing.

Dari tabel di atas dapat diperoleh persamaan regresi linier berganda sebagai berikut :

$\mathrm{Y}=0,692+0,182\left(\mathrm{x}_{1}\right)+0,209\left(\mathrm{x}_{2}\right)+0$, $473\left(\mathrm{x}_{3}\right)$

Dimana :

0,692 = variabel independen yaitu minat pelanggan yang terdiri dari advertising, personal selling, direct marketing, minat pelanggan mempunyai hubungan positif dengan peningkatan minat pelanggan. Nilai konstanta mint pelanggan sebesar 0,692 menunjukkan bahwa semakin seringnya promosi dilakukan maka akan berpengaruh pada minat pelanggan untuk menggunakan listrik prabayar.

0,182 = besarnya koefisien variabel advertising yang berarti setiap peningkatan variabel advertising sebesar $1 \%$ maka minat pelanggan meningkat 0,182 dengan asumsi variabel lainnya (personal selling, direct marketing, minat pelanggan) konstan.

$0,209=$ besarnya koefisien variabel advertising yang berarti setiap peningkatan variabel personal selling 
sebesar $1 \%$ maka minat pelanggan meningkat 0,209 dengan asumsi variabel lainnya (advertising, direct marketing, minat pelanggan) konstan.

$0,473=$ besarnya koefisien variabel advertising yang berarti setiap peningkatan variabel direct marketing sebesar 1\% maka minat pelanggan meningkat 0,473 dengan asumsi variabel lainnya (advertising, personal selling, kinerja perusahaan) konstan.

Tabel 4.11

Nilai $R$

Model Summary

\begin{tabular}{l|l|l|l|l}
\hline \multicolumn{1}{c|}{ Model } & $\mathrm{R}$ & $\mathrm{R}$ Square & $\begin{array}{c}\text { Adjusted R } \\
\text { Square }\end{array}$ & $\begin{array}{c}\text { Std. Error of the } \\
\text { Estimate }\end{array}$ \\
\hline 1 & $0,716^{\mathrm{a}}$ & 0,512 & 0,497 & 0,22855 \\
\hline
\end{tabular}

a. Pedictors : (Constant), X3 (Direct Marketing), X2 (Personal Selling), X1 (Advertising) Sumber : Data diolah

Hasil perhitungan $\mathrm{R}$ pada tabel 4.11, yaitu menunjukkan gambaran pengaruh antara variabel bebas yang terdiri dari advertising (X1) dan personal selling (X2), direct marketing (Y) terhadap variabel terikat yaitu kinerja perusahaan (Y). Nilai $\mathrm{R}$ sebesar 0,716 atau 71,6\% menggambarkan hubungan antara variabel bebas dan variabel terikat bersifat searah dan kuat. Sedangakan nilai $\mathrm{R}$ square atau determinan $\mathrm{R}$ sebesar 0,512 atau 51,2 $\%$ pengaruh secara simultan sedangkan sisanya $(100 \%-51,2 \%=$ $48,8 \%$ ) dipengaruhi oleh faktor lain yang tidak diteliti dalam penelitian ini.

Koefisien determinasi $\left(\mathbf{R}^{\mathbf{2}}\right)$ yang ditunjukkan oleh angka $\mathbf{R}$ square adalah hasil pengkuadratan dari koefisien korelasi berguna untuk mengukur besarnya persentase andil variabel independen terhadap variabel variabel dependen. Nilai $R^{2}$ dari penelitin ini dalah 0,512 artinya, bahwa kinerja dapat dijelaskan oleh ke-tiga variabel independen yaitu (advertising, personal selling, direct marketing) sebesar $51,2 \%$, sedangkan sisanya sebesar $48,8 \%$ dijelaskan oleh faktor lain yang tidak dimasukkan dalam penelitian ini.

\subsubsection{Uji Hipotesis}

\section{a. Uji F (Simultan)}

Uji simultan atau uji $F$ merupakan uji secara bersama-sama untuk menguji signifikan pengaruh variabel kualitas pelayanan yang terdiri atas advertising, personal selling, dan direct marketing, bersama-sama mempunyai pengaruh yang positif dan signifikan terhadap variabel kepuasan pelanggan. 
ISSN 1412-2936

EISSN 2549-7308

Tabel 4.12

Uji F

Anova $^{a}$

\begin{tabular}{ll|l|l|l|l|l}
\hline Model & $\begin{array}{l}\text { Sum of } \\
\text { squares }\end{array}$ & Df & $\begin{array}{l}\text { Mean } \\
\text { Square }\end{array}$ & F & Sig. \\
\hline 2 & $\begin{array}{l}\text { Regression } \\
\text { Residual }\end{array}$ & 5.208 & 3 & 1,736 & 33,235 &, $000^{\mathrm{b}}$ \\
& \begin{tabular}{l} 
Total \\
\multicolumn{1}{l|}{}
\end{tabular} & 10,962 & 95 & 0,052 & & \\
\hline \multicolumn{2}{c|}{} & Dependent Varabel : Y (Kinerja perusahaan) & 98 & & & \\
\hline
\end{tabular}

b. Predictors : (constant), X3 (Direct Marketing), X2 (Personal Selling), X1 (Advertising)

Sumber : Data diolah

Dari hasil regresi dari tabel 4.12 menunjukkan $\mathrm{F}$ hitung sebesar $33,235 \mathrm{~m}$ sedangkan hasil $\mathrm{F}$ tabel 2,70. Hal ini berarti $F$ hitung $>F$ tabel $(33,235>2,70)$ signifikan. Perhitungan tersebut menunjukkan bahwa kumunikasi yang terdiri atas advertising, personal selling, direct marketing secara bersam-sama mempunyai pengaruh yang positif dan signifikan terhadap variabel minat pelanggan.

\section{b. Uji T (Parsial)}

Pengujian secara parsial (Ujit) digunakan untuk menguji pengaruh variabel bebas terhadap variabel terikat secara parsial atau secara individual, dan dapat pula digunakan untuk melihat pengaruh variabel bebas yang paling dominan. Secara teknis pengujiannya dilakukan dengan membandingkan nilai $t_{\text {hitung }}$ dengan nilai $t_{\text {tabel }}$ pada taraf signifikansi $\alpha=0,05$

Berdasarkan hasil perhitungan pada lampiran, maka hasil pengujian secara parsial (uji-t) dapat disajikan pada tabel berikut :

Tabel 4.13

Uji t

Coefficients $^{\mathrm{a}}$

\begin{tabular}{|c|c|c|c|c|c|c|c|c|c|c|}
\hline \multirow{2}{*}{$\begin{array}{l}\text { Model } \\
\text { - }_{\text {(Constan })}\end{array}$} & \multicolumn{2}{|c|}{$\begin{array}{l}\text { Unstandardized } \\
\text { Coefficients }\end{array}$} & \multirow{2}{*}{$\begin{array}{l}\begin{array}{l}\text { Standardized } \\
\text { Coefficients }\end{array} \\
\text { Beta }\end{array}$} & \multirow{2}{*}{$\begin{array}{l}\mathrm{T} \\
1,552\end{array}$} & \multirow{2}{*}{$\begin{array}{l}\text { Sig. } \\
0,124\end{array}$} & \multicolumn{3}{|c|}{ Correlations } & \multicolumn{2}{|c|}{$\begin{array}{l}\text { Collinearity } \\
\text { Statistics }\end{array}$} \\
\hline & $\begin{array}{l}\mathrm{B} \\
0,692\end{array}$ & $\begin{array}{l}\text { Std. Error } \\
0,446\end{array}$ & & & & $\begin{array}{l}\text { Zero- } \\
\text { order }\end{array}$ & Partial & Part & Tolerance & VIF \\
\hline $\begin{array}{l}\text { X1 } \\
\text { (Advertising) }\end{array}$ & 0,182 & 0,057 & 0,244 & 3,181 & 0,002 & 0,106 & 0,310 & 0,228 & 0,874 & 1,144 \\
\hline $\begin{array}{l}{ }^{1} \text { X2 (Personal } \\
\text { Selling) }\end{array}$ & 0,209 & 0,090 & 0,215 & 2,335 & 0,022 & 0,455 & 0,233 & 0,167 & 0,608 & 1,646 \\
\hline $\begin{array}{l}\text { X3(Direct } \\
\text { Marketing) }\end{array}$ & 0,473 & 0,071 & 0,579 & 6,654 & 0,000 & 0,677 & 0,564 & 0,477 & 0,679 & 1,472 \\
\hline
\end{tabular}


Berdasarkan

hasil perhitungan tabel 4.13 diperoleh $\mathrm{t}_{\text {hitung }}$ untuk variabel advertising $\left(\mathrm{X}_{1}\right)$ sebesar 3,181; nilai $t_{\text {hitung personal }}$ selling $\left(\mathrm{X}_{2}\right)$ sebesar 2,335, dan nilai $\mathrm{t}_{\text {hitung direct marketing sebesar } 6,654}$ dan jika dikonsultasikan dengan $\mathrm{t}$ tabel sebesar 1,664 sehingga t hitung $>$ dari t tabel dengan demikian dapat disimpulkan bahwa advertising (X1), personal selling (X2), dan direct marketing (X3) berpengaruh terhadap kinerja perusahaan (Y) dapat dibuktikan kebenarannya.

Dari hasil perhitungan dengan menggunakan uji t, ternyata dari tiga variabel bebas tersebut yang meliputi advertising (X1) personal selling (X2), dan direct marketing yang memiliki nilai $t$ paling besar adalah direct marketing (X3) yaitu sebesar 66,54\%, dengan demikian dapat disimpulkan bahwa direct marketing berpengaruh dominan terhadap kinerja perusahaan dengan menggunakan listrik prabayar di PT. PLN (Persero) Rayon Ketapang, Kabupaten Sampang.

\section{KESIMPULAN DAN SARAN}

Berdasarkan hasil dari pembahasan penelitian ini, maka pada bab v ini kan peneliti jelaskan beberapa kesimpulan dan saran sebagai berikut:

\subsection{Kesimpulan}

a. Hipotesis statistik yang pertama berbunyi "promosi yang terdiri dari advertising, personal selling, dan direct marketing berpengaruh secara simultan terhadap minat pelanggan untuk menggunakan listrik prabayar di PT. PLN (Persero) Rayon Ketapang Kabupaten Sampang dapat dikatakan kebenarannya, ini dibuktikan dengan hasil SPSS dengan taraf nyata $10 \%$ dengan tingkat keyakinan $90 \%$ diperoleh $F_{\text {hitung }} 33,235$ sedangkan $F_{\text {tabel }} 2,70$.

b. Hipotesis statistik kedua yang berbunyi "variabel yang dominan berpengaruh terhadap minat palanggan munggunakan listrik prabayar di PT. PLN (Persero) Rayon Ketapang adalah variabel direct marketing" dapat diterima, hal ini dibuktikan dengan nilai $t_{\text {hitung }}$ untuk direct marketing sebesar 6,654 dari nilai $t_{\text {hitung }}$ tersebut ternyata $t_{\text {hitung }}$ direct marketing paling besar jika dibandingkan dengan $t_{\text {hitung variabel }}$ bebas lainnya.

c. Dari hasil perhitungan nilai $\mathrm{R}$ sebesar $71,6 \%$ yaitu menggambarkan hubungan antara variabel bebas terhadap variabel terikat searah dan kuat.

d. Nilai $R$ squared atau determinan sebesar 0,512 atau $51,2 \%$ hal ini menunjukkan bahwa tingkat minat pelanggan dapat dijelaskan oleh ke lima variabel independen yaitu (advertising, personal selling, direct marketing) sedangkan sisanya sebesar 48,8 dijelaskan oleh faktor lain yang tidak dimaksukkan dalam penelitian ini.

\subsection{Saran}

Saran yang dapat dikemukan khususnya kepada PT. PLN (Persero) Rayon Ketapang Kabupaten Sampang adalah :

1. Meningkatkan kemudahan akses pelanggan pada Dinas Gangguan Listrik, dengan menambah operator penerima telepon di dinas/unit tersebut agar pelanggan yan melaporkakn gangguan teknis segera bisa diterima.

2. Informasi mengenai pemadaman listrik melalui radio, ternyata tidak 
terlalu efektif sampai kepada pelanggan, sehingga perlu dikreasi upaya lain agar penyampain informasi tersebut lebih efektif.

3. Meningkatkan hubungan contact personantara petugas dengan dengan pelanggan, PT. PLN (Persero) Rayon Ketapang.

4. Terus melakukan inovasi promosi listrik prabayar agar kedepannya lebih bisa menarik minat pelanggdndarmanto.2005. Metodelogi Sosial Konsep untuk menggunakan listrik prabayar.

\section{DAFTAR PUSTAKA}

Angipora Mairus P. 2002. Dasar- Dasar Pemasaran. PT. Raja Girafindo Persada;Jakarta. 2007. Perencanaan, Aplikasi, dan Pengembangan Indikator Kinerja Utama Bisnis dan Publik, Rajawali Pers; Jakarta.

Arikunto. 2006. Prosedur Penelitian Suatu Pendekatan Praktik. PT.Rineka Cipta; Jakarta.

Assauri.2007. Manajemen Pemasaran Jasa. Edisi Ketiga. Salemba Empat ; Jakarta.

Chandra . 2006. Metode Penelitian. Ghalia Indonesia; Jakarta.

Danim.2000. Memandu Metode Penelitian Kualitatif dan Kuantitatif. Pustaka Pelajar; Yogyakarta.

Ferdinand A. 2002. Structural Equation Modeling Dalam Penelitian Manajemen. Edisi 2, Seri Pustaka Kunci 03/BP UNDIP.

Handoko, Dharmista. 2002. Perilaku Konsumen. Edisi Kedua. PT. Ghalia Indonesia; Jakarta.

Harrison. 2009. Metode Penelitian Suatu Pendekatan Praktik. PT.Rhineka Cipta ;Jakarta.

Isnain .2005. Strategi Promosi Yang Kreatif. Edisi Pertama.Cetakan Pertama. Gramedia Pustaka Utama; Jakarta.
Jefkins .2004. Sistem Perencanaan dan Penegendalian Manajemen: Sistem Melipat Ganda Kinerja Perusahaan. penerbit: Salemba Empat; Jakarta.

Santoso Singgih. 2009. Panduan Lengkap Menguasai Statistik Dengan SPSS.

BPFE; Yogyakarta.

Prosedur Dan Konsep. Salemba Empat; Jakarta

Sugiono. 2002. Statistika Untuk Penelitian. Alfabeta; Bandung.

2003. Metode Penelitian Kualitatif, Kuantitatif Dan R\&D. Alfabeta; Bandung.

2015. Metode Penelitian

Pendidikan Pendekatan

Kuantitatif dan Kualitati

R\&D. Alfabeta ; Jakarta.

Kotler, Philip. 2008 . Prisip-Prinsip

Manajemen Pemasaran.

Edisi 12. Jilid 1 Erlangga;

Jakarta.

Kevin Lane Ketler. 2008. Manajemen

Pemasaran. Terjemahan.

$\begin{array}{lr}\text { Pemasaran. } & \text { Manajemen } \\ \text { Yogyakarta. } & \text { ANDI: }\end{array}$

Oroh, Sem G.2007. Penerapan

Strategi Promosi pada

Pemasaran Produk.

Federal Parts CV. Kanaka Jaya

Manado.Universitas

SamRatulangi; Manado.

Lupiyoadi Rambat. 2013. Manajemen

Pemasaran Jasa. Edisi

Tiga. Salemba Empat: Jakarta.

Moleong. 2002. Metodologi Penelitian Kualitatif . PT.Remaja Rosdakarya: Bandung. 
ISSN 1412-2936

EISSN 2549-7308

2011.

Metodologi

Penelitian Kualitatif (Edisi Refisi).

PT.Remaja

Rosdakarya; Bandung.

Nasution. 2009. Metodologi Penelitian Naturalistik Kualitatif. Tarsito; Bandung.

Rival dan Basri. 2004. Metodologi

Penelitian. Edisi 1. Andi;

Yogyakarta.

Saladin,djaslim. 2007. Manajemen

Pemasaran. Edisi Pertama.Cetakan

Keenam BPFE; Yogyakarta.

Shimp . 2003. Manajemen Pemasaran dan

Pemasaran Jasa. Alfabeta CV;

Bandung

Sugiono. 2008. Metode Penelitian

Kuantitatif, Kualitatif dan R\&D.
Cetakan ke 11. CV. Alfabeta; Bandung.

Swastha . 2000. Dasar-Dasar Periklanan. Politeknik Pos Indonesia; Bandung.

Jurnal

Putri, Rahma. 2003. Promosi PT. PLN (Persero) Distribusi Jakarta Raya dan Tanggerang Dalam Mendukung Brand Awerness listrik pintar.Universitas Bina: Nusantara. 